CESIS Electronic Working Paper Series

Paper No. 449

\title{
The impact of open innovation on employee mobility and entrepreneurship
}

\author{
Markus Simeth \\ Ali Mohammadi
}

March, 2017 


\title{
The impact of open innovation on employee mobility and entrepreneurship
}

\author{
Markus Simeth $^{\text {a }}$ \\ Ali Mohammadi ${ }^{b}$
}

Preliminary draft: February 2017

Please do not quote without authors' permission

\begin{abstract}
Prior research shows that firms can increase their innovation performance by leveraging external sources of knowledge. However, insights related to potential drawbacks of open collaborative approaches for innovation remain scarce. In this paper, we investigate the relationship between $R \& D$ collaboration and the departure of skilled employees. Highly qualified scientists and engineers who interact with external partners in the context of R\&D collaborations may increase their outside options, resulting in higher rates of employee mobility to other firms and employee entrepreneurship. We analyze our research question using data from the Swedish edition of the Community Innovation (CIS) survey combined with employeremployee register data. Our econometric analysis suggests that a stronger use of research collaborations by firms leads to an increasing number of employee departures. Moreover, we detect heterogeneity for this relationship with respect to the types of employee exits and different collaboration partners.
\end{abstract}

Keywords: R\&D employees, Open Innovation, R\&D Collaboration, Employee mobility, Employee Entrepreneurship

JEL codes: O32, J62

\footnotetext{
a Universidad Carlos III de Madrid (UC3M), Department of Business Administration, 28903 Getafe, Spain. Corresponding author. Email: markus.simeth@uc3m.es

${ }^{\mathrm{b}}$ Royal Institute of Technology (KTH), Department of Industrial Economics and Management, 10044 Stockholm, Sweden. Email: ali.mohammadi@indek.kth.se and Swedish House of finance, ali.mohammadi@hhs.se.
} 


\section{Introduction}

For innovative companies, highly qualified researchers and engineers can be considered as one of the most important key resources for creating innovative products and ultimately firm performance (Barney 1991; Toivanen and Väänänen 2012). However, employees may leave to other firms which implies a loss of valuable human capital for their current employer (Coff 1997; Gompers et al. 2005; Fallick et al. 2006; Franco and Filson, 2006; Campbell et al. 2012; Ganco et al. 2015). It can be challenging for the current firm to substitute adequately the leaving employee with new hires, and extensive training might be necessary in order to integrate new employees (Campbell et al. 2012). In addition, the departure of researchers and engineers may have negative competitive effects due to the occurrence of knowledge spillovers given that employees can apply the obtained knowledge, skills, and network ties at the recipient firm (Cooper 2001; Fallick et al. 2006; Franco and Filson 2006; Wezel et al. 2006; Agarwal et al. 2009; Maliranta et al. 2009).

Correspondingly, empirical studies provide ample evidence for the positive effects of incoming R\&D workers on recipient firms' innovation and firm performance, whereas the departure of key employees has potentially negative implications for the previous firm (Rosenkopf and Almeida 2003; Song et al. 2003; Kaiser et al. 2015; Singh and Agrawal 2011; Palomeras and Melero 2010; Parrota and Pozzoli 2012). Consequently, identifying determinants of employee mobility and related managerial actions to reduce the rate and consequences are an important task for firms and scholars alike (Ganco et al. 2015; Kim and Marschke 2005). Prior studies identified several determinants of employee mobility and employee entrepreneurship such as the characteristics and complexity of knowledge that an inventor holds, the utilization degree of the inventor's knowledge by the current organization, and the availability of complementary assets (Hellmann 2007; Palomeras and Melero 2010; Campbell et al. 2012; Ganco 2013; Gambardella et al. 2015).

This paper will contribute to this line of research by providing new insights regarding determinants of employee exits. In particular, we contend that the extent as to which firms leverage external sources of knowledge for their innovation processes impacts the likelihood that R\&D employees move to other firms 
(employee mobility) or create own ventures (employee entrepreneurship). Due to the increasing complexity and costs of $R \& D$, it is increasingly challenging for firms to conduct all required $R \& D$ activities in-house. As a consequence, many firms rely heavily on external knowledge for their innovation creation processes and leverage different sources such as universities, users, and suppliers (see Chesbrough 2003; Dahlander and Gann 2010). Empirical research demonstrated that those firms which use external sources for innovation and engage in formal research collaboration achieve higher innovation productivity (e.g. Cassiman and Veugelers 2006; Laursen and Salter 2006; Cassiman and Valentini 2015).

However, a positive average effect of external sources on innovation productivity may be subject to boundary conditions and from a methodological point of view, the documented benefits are potentially associated with specific costs that are imperfectly captured by standard innovation output measures. In this respect, the evidence on costs and boundary conditions of such “Open Innovation” practices remain scarce. A notable exception is the study by Giarratana and Mariani (2014) who show that firms increase their commitment to internal R\&D (as opposed to external knowledge sources) if the perceived imitation risk is high. Moreover, Laursen and Salter (2006) have shown that the relationship between openness and innovation performance is not linear, i.e. that a strong use of external sources leads to diminishing returns. However, it remains unclear which micro-mechanisms are driving this empirical observation.

We argue that leveraging external partners for innovation, in particular by means of formal research collaboration, increases the outside options of R\&D employees and results in an increasing rate of employee exits. In this respect, employees may not only consider other firms as prospective employers but the relevant skills, knowledge, and social capital obtained through interactions with collaboration partners may also prove helpful for employee entrepreneurship. Through continuous interactions with R\&D personnel in other firms, individual researchers increase their visibility and build up reputation, finally making the boundaryspanning researcher attractive for the interacting partner to recruit. Similarly, these interactions with other researchers and partners may help employees to shape entrepreneurial ideas and to establish crucial contacts, for instance with customers or suppliers. 
The quantitative empirical analysis relies on the combination of two main data sources that constitute together a rich dataset. Specifically, we link firm-level data from the Swedish Community Innovation survey (CIS) with individual-level data from the Swedish employer-employee register data. The former data source allows us to capture the extent as to which firms are engaged in research collaboration, whereas the employer-employee data provides exhaustive information about the mobility events related to firms' employees. The final firm-level sample comprises of 8,012 firm-year observations (4,608 distinct firms).

Our econometric analysis provides evidence that a stronger use of external partners for innovation, as measured by the breadth of formal research collaboration, increases the rate of employee exits. This relationship is particularly pronounced for mobility of employees to other firms, whereas we obtain a smaller and partially statistically insignificant effect for employee entrepreneurship. Moreover, collaboration with competitors and customers leads to higher magnitudes, whereas collaboration with suppliers and academic partners does not imply increasing rates of mobility. Finally, we also obtain suggestive evidence through a complementary individual level analysis that particularly high-ability employees are able to increase their outside options.

\section{Literature Review}

This paper draws from two main lines of literature, namely studies analyzing the determinants of employee mobility on the one hand, and studies related to external knowledge sourcing, research collaboration, and Open Innovation on the other hand. With regard to the determinants of mobility, Palomeras and Melero (2010) provide evidence that inventor's knowledge characteristics, such as the complementarity with knowledge held by other inventors in the firm, determine the likelihood of employee departures. Ganco (2013) shows that the complexity of inventors’ prior patenting activities influences the inventors' decision to join rival companies or to become entrepreneurs. Whereas complex knowledge tends to inhibit employee mobility to rival firms, the under-exploitation of this knowledge by the existing organization increases entrepreneurship. Similarly, Gambardella et al. (2015) and Hellmann (2007) identify 
the inventor's valuation of an invention and the utilization degree of an invention by the employing firm as important determinants for employee mobility. Campbell et al. (2012) stress the role of the transferability of employees' assets to other contexts as determinant of exit decisions. Furthermore, poor firm performance (Williams and Livingstone 1994), misspecified compensation schemes (Zenger 1992; Carnahan et al. 2012), weak employer-employee fit (Sheridan 1992), disagreement with top-management, and desire for autonomy have been identified as relevant drivers for employee mobility (Elfenbein et al. 2010; Klepper and Thompson 2010). Specifically related to employee entrepreneurship, Agarwal et al. (2004) suggest that firms’ technological and market know-how stimulates or reduces spin-out likelihood.

A related line of scholarly inquiry is concerned with the performance effects of employee mobility at the recipient and source firms. The empirical studies are consistent in documenting positive effects of hiring new R\&D employees on inventive and firm performance at the level of the recipient firm (Parrotta and Pozzoli 2012; Kaiser et al. 2015). Regarding the underlying micro-mechanisms, empirical studies suggest, among other reasons, that new employees may allow firms to access technologically distant knowledge (Palomeras and Melero 2010; Rosenkopf and Almeida 2003). With respect to the effect of employee mobility to source firms, there is mixed evidence. Although some studies provide suggestive evidence for positive feedback effects of employee mobility to the source firms (Kaiser et al. 2015; Rosenkopf and Correida 2010), other empirical studies point directly or indirectly to negative effects of mobility (Singh and Agrawal 2011; Campbell et al. 2012).

Acknowledging the negative implications of employee exits, complementary studies provide insights on how firms can actively manage the risks of mobility. Kim and Marschke (2005) document that those firms facing high risks of leaving key employees increase their propensity to patent, which does not necessarily prevent the mobility event per se but minimizes the potential spillovers imposed by the employees' departure. Relatedly, firms' inclination towards aggressively engaging in patent litigation also reduces spillover risks from employee mobility (Agarwal et al. 2009). It also has been shown that the effectiveness of non-compete agreements may limit the risk of employee mobility (Franco and Mitchell 
2008; Marx et al. 2009; Samila and Sorenson 2011). Finally, firms with wage compensation schemes that reward adequately highly productive inventors also can reduce mobility (Carnahan et al. 2012).

The second major line of literature is concerned with the access of firms to external knowledge, such as through formal research collaboration, licensing, absorbing spillovers, and informal sourcing modes. The vast majority of studies in the applied economics and management literatures identify positive effects of the use of external knowledge on innovative performance. In other words, the consideration of external knowledge, regardless whether it is done in the context of formal collaboration or by more informal means, increases firms’ R\&D productivity (e.g. Rosenkopf and Nerkar 2001; Cassiman and Veugelers 2002; Katila and Ahuja 2002; Laursen and Salter 2006; Bloom et al. 2013; Cassiman and Valentini 2015). The underlying reason behind this observation rests on the consideration that firms cannot keep up with all relevant scientific and technological opportunities in-house, or an exclusive internal knowledge generation is at least not efficient.

Whereas the positive effect of external knowledge on firms' innovation performance is hardly subject of debates, there is reason to assume that boundary conditions and specific costs of openness exist. Although they document in general positive innovation performance effects of Open Innovation, Laursen and Salter (2006) provide also evidence that a too strong use of external sources leads to diminishing returns. A specific cost is an increasing imitation risk as a result of openness. The interactions with external partners for insourcing knowledge may also imply higher risks of knowledge outflows (Giarratana and Mariani 2014). Specifically related to formal collaboration agreements, a higher number of collaborations is associated with increasing coordination and governance costs (e.g. Grimpe and Kaiser 2010). In the following section 3, we shed light on a further potential specific cost of openness and research collaboration, namely increasing rates of employee mobility and entrepreneurship. 


\section{Theoretical background and hypotheses}

\section{The relationship between $R \& D$ collaboration and exit decisions of skilled employees}

The implementation of firm strategies directed to the access to external knowledge is strongly connected to the abilities and actions of the employed scientists and engineers. The internal R\&D personnel act as boundary spanners as they search for external technological solutions and interact with colleagues in other companies and academic institutions in the context of collaborations (Dahlander et al. 2014; Gruber et al. 2013; Toivanen and Väänänen 2012). From a theoretical viewpoint, several mechanisms which may establish a relationship between Open Innovation activities and employee mobility may apply. Specifically, firm-level open innovation strategies may affect employees' knowledge base, the interacting firms may have reduced screening costs for hiring new employees, and openness may also lead to lower search costs for the R\&D employees themselves concerning potential outside employment options.

First, R\&D employees in firms that are engaged in external knowledge sourcing may sustain to a higher degree skills, knowledge, and social capital which are not firm-specific (Coff 1997; Hatch and Dyer 2004; Campbell et al. 2012b). The R\&D employees who search for innovation outside the boundaries of the firm are exposed to a broader set of knowledge, different problem-solving approaches, and are potentially also to a lesser degree embedded in firm-specific routines (Liu and Stuart 2011). Moreover, firms that frequently interact with partners should possess a diverse professional network with employees in other firms and institutions. Therefore, R\&D employees of more open firms should have, on average, a more versatile knowledge and skill base than R\&D employees in "closed" firms, which may imply more employment options outside their current firm (see Fleming and Waguespack 2007).

From the viewpoint of firms which intend to hire new employees, those R\&D workers already known from joint collaborative activities are particularly attractive candidates. The preceding collaboration reduces the uncertainty about the employees' abilities, and the fit between candidates with the hiring organization can be assessed at comparatively low costs (Spence 1973; Oyer and Schaefer 2010; Bidwell and Keller 2014). Moreover, also direct search costs are presumably lower since no open call hiring process has to be 
initiated for identifying highly capable $R \& D$ employees. As a matter of fact, the more intensely $R \& D$ employees interact with other companies, the more information about the employee's characteristics and ability is known to the collaboration partner firms. Therefore, the information asymmetry is likely particularly reduced in setting of formal research collaborations and strategic alliances given that they imply frequent individual interactions. Moreover, the formation of research collaborations indicates a basic complementarity between the collaboration partners which should also find expression at the individual level. Whereas collaboration may serve as a short-term solution to overcome constraints of local search and limited in-house capabilities, hiring employees from the collaboration partner may allow for building up own capabilities (Blyler and Coff 2003; Rosenkopf and Almeida 2003; Palomeras and Melero 2010).

From the viewpoint of the R\&D employees who are designated to collaborative projects, an increasing tendency for mobility can be similarly expected. These employees presumably know the scientific and technological landscape very well due to their efforts to search for external technological solutions, including the research institutions and companies which are engaged in the production of complementary knowledge and technologies (see Powell et al. 1996). The R\&D employees’ individual search activity allows them to assess the technological positioning of other companies and to obtain insights with respect to the skills and knowledge base that were required to produce the research outcomes of these firms (see Fleming and Sorenson 2004; Gruber et al. 2013). In other words, boundary-spanning R\&D employees should be able to assess the fit between their own skills and the requirements associated with an employment in other companies. Consequently, they may have less search costs to identify potential outside options if they look actively for new jobs, which may similarly lead to an increasing rate of mobility. Accordingly, we formulate the baseline hypothesis:

H1: A stronger reliance of firms on research collaborations increases employee mobility to other firms and employee entrepreneurship. 


\section{Employee mobility vs. employee entrepreneurship}

Previous studies distinguish employee departures according to the two categories employee mobility (i.e. inter-firm mobility) and employee entrepreneurship (Carnahan et al. 2012; Campbell et al. 2012; Gambardella et al. 2015). We expect this distinction also being meaningful with regard to the impact of Open Innovation strategies on mobility. As outlined in the previous section, employees who collaborate with $R \& D$ scientists in other organizations may receive direct employment opportunities at the partnering firm due to reduced screening costs, and the collaboration partner may even actively "pull” for the employee (Levin et al. 1987; Palomeras and Melero 2010). By default, such a hiring-away mechanism does not apply in the context of employee entrepreneurship. Although it is possible that boundary-spanning employees find potential co-entrepreneurs or staff members in the collaborating firm, a direct pull effect is unlikely to be prevalent.

Furthermore, R\&D staff who interact with peers from the collaboration partner may obtain knowledge and create social capital that are not of equal value with regard to mobility to other firms and entrepreneurship. Although motives for $\mathrm{R} \& \mathrm{D}$ collaborations are heterogeneous, there are typically technology-oriented motives at place such as combining resources for basic or applied research and to master jointly technological complexity (Hagedoorn 1993; Belderbos et al. 2004). As a result, the interactions between researchers across organizational boundaries should have a strong focus on technology-related aspects (see also Bouty 2000). The resulting exchanges may increase focal R\&D employees' technological knowledge base and thus increase their options to find employment in other firms. Although the technical knowledge base may also be useful for the potential transition of an employee to entrepreneurship, starting new ventures requires additional skills, knowledge, and network ties. In particular, a successful venture creation is inherently tied to the availability of managerial and businessrelated skills and network ties (Agarwal and Audretsch 2001; Agarwal et al. 2004). Some R\&D collaborations are also set up for motives related to market access and search for opportunities (Hagedoorn 1993; Chatterji and Fabrizio 2014). Therefore, R\&D collaborations may also increase the skills and 
knowledge with regard to market related knowledge. This may particularly apply to collaborations with users. However, we contend that, on average, technology-related exchanges are dominant in R\&D collaborations. Therefore, and in line with the consideration of potential pull effects, we expect the effect of R\&D collaborations on employee exits to be larger for inter-firm mobility:

H2: A stronger reliance of firms on research collaborations has a stronger impact for employee mobility to other firms than for employee entrepreneurship.

\section{Collaboration partner heterogeneity}

The impact of research collaborations on employee mobility may also depend on the type of the particular collaboration partner. Previous literature frequently distinguishes between universities, competitors, suppliers, and users as partners for research collaboration (e.g. Belderbos et al. 2004). Collaboration with universities may allow company researchers to acquire new social capital, knowledge about the latest academic findings, and technical research skills. As a result of the interactions with university researchers, $R \& D$ researchers in firms may have a strong individual-level absorptive capacity and superior knowledge recombination abilities, and due to potential scientific co-publications and the associated visibility, they are straightforward to identify for other companies (Cockburn and Henderson 1998; Fleming and Sorenson 2004). However, unlike in the case of collaborative research with other firms, partnerships with universities are unlikely to generate direct employment opportunities. Given the hypercompetitive environment in academe and the excess supply of $\mathrm{PhD}$ graduates for faculty positions, mobility of industrial researchers to academic institutions remain a scarce phenomenon (see Stephan 2012). Therefore, in the absence of employment options directly arising from a science-industry collaboration, we expect that such collaborations have a smaller impact on mobility than collaborations with firms. However, even with respect to different firm types serving as potential collaboration partners, some heterogeneity can be expected. Collaborations with competitors are frequently established based on the underlying idea to absorb specific skills currently not available in the firm (e.g. Hamel et al. 1989). At the same time, 
collaborations with rivals are inherently unstable and there are typically little incentives for long-term considerations. In other words, competitors have little reason to hesitate for hiring away employees from the collaboration partner. This distinguishes collaborations of competing firms from those with supply chain partner suppliers and users. Previous research suggests that supply-chain partners may have incentives to invest in long-term relationships (see Kotabe et al. 2003; Alcacer and Oxley 2013; Isaksson et al. 2016). In this regard, explicit hiring-away attempts between supply-chain partners could be detrimental for establishing and maintaining long-term relationships.

H3a: Research collaborations with academic institutions have a lower impact on employee exits than collaboration with firms.

H3b: Collaboration with competitors have a higher impact on employee exits than collaborations with suppliers and users.

\section{Data and Methodology}

\section{Dataset and Variables}

The empirical analysis is conducted using an original dataset which is composed of two main data sources. First, we obtained the information on firms' collaboration strategies from the Swedish edition of the Community Innovation Survey (CIS). The CIS surveys have been frequently used to study phenomena related to Open Innovation and research collaboration (e.g. Laursen and Salter 2006; Cassiman and Veugelers 2002). The Swedish CIS is administered every other year and we use five rounds comprising of the editions of 2004, 2006, 2008, 2010, and 2012. We restrict our analysis to R\&D performing companies with a minimum size of 10 employees. This dataset is combined with the Swedish employer-employee registry data provided by Statistics Sweden (SCB). This second data source contains exhaustive information about the composition of the Swedish labor workforce and employee mobility events (Mohammadi et al. 2016). Although the firms and the individuals in the datasets are anonymous, unique identification codes 
for employees and employers allow for linking employees to firms. Our final sample contains 8,012 firmyear observations (4,608 distinct firms).

In order to measure the departure of employees, and to differentiate between employee mobility to other firms and entrepreneurship (see Campbell et al. 2012), we compute two different variables at the firm-level: (1) the number of employees moving to another firm and (2) the number of employees who start a new venture or become self-employed. In this respect, both measures are restricted to employees that are highly skilled according to the Swedish Standard Classifications of Occupations (SSYK) given our interest in the mobility of R\&D employees (see Mohammadi et al. 2016).

The activities of firms with respect to research collaboration are obtained from the CIS survey and we consider several well-established measures frequently used in the literature. First, we compute a dummy variable that captures whether a firm is engaged in any formal research collaboration regardless the type of the partner (Collaboration). Second, we count the number of distinct partners in order to obtain a measure on collaboration breadth (Collaboration Breath). This measure varies between 0 and 5 depending on whether firms collaborate with competitors (Competitor Collaboration), customers (Customer Collaboration), suppliers (Supplier Collaboration), academic institutions (Academic Collaboration), and external subsidiaries of the same company (Internal Collaboration). Third, in order to disentangle potentially distinct effects of different partner types, we compute separate dummy variables for each of these categories.

We introduce a comprehensive set of control variables in all our regression models in order to take firmheterogeneity into account. We include the average salary level (Avg salary) as well as the salary dispersion level (Salary standard dev) in the firm since the compensation structure and the associated reward structure may influence the rate of employee mobility (see Zenger 1992; Carnahan et al. 2012). We also control for the lagged firm profitability (ROA) since the financial success of the firm is likely associated with the internal innovation capabilities of firms, the extent to which firms are considering external partners for innovation (see Williams and Livingstone 1994; Garriga et al. 2013), and the quality of the work climate in 
the company which potentially determine the rate of mobility. We also control for the $R \& D$ intensity and the firm size as measured by the number of employees. Finally, we include measures to control for a firm's ownership status, the share of $\mathrm{PhD}$ trained researchers, the share of female employees in the firm, whether firm is a start-up firm (<10 years), as well as industry and year dummies. The following Tables 1 and 2 show descriptive statistics and bi-variate correlations for the abovementioned variables. Figure 1 represents a histogram of our core independent variable collaboration breadth.

-- Insert Table 1, Table 2, and Figure 1 about here --

On average, around 9 employees leave the company to work in other firms in a given year, whereas less than 1 employee starts their own company. With regard to the independent variables of interest, around 50\% of our sample firms are engaged in at least one $R \& D$ collaboration. The average number of distinct collaboration partners is 1.5. When we decompose this number according to the collaboration partner types, we observed that $40 \%$ collaborate with suppliers, $27 \%$ with customers, $18 \%$ with competitors, and $38 \%$ with universities and public research institutes.

Moreover, the average annual salary amounts to 415,000 Swedish Kronors (which is equivalent to 44,000 USD, or around 42,000 EUR). The coefficient of the salary standard deviation, which measures the wage dispersion within the firm, is $43.9 \%$. Concerning the demographic composition of the R\&D workforce, around $25 \%$ of the employees are female and $2 \%$ have a PhD degree. Firms spent on average the equivalent of $8.2 \%$ of their sales on R\&D and achieve an average return on assets of 3.8\%. Moreover, $34 \%$ of our sample firms are younger than 10 years and the average firm size is 67 employees. Finally, with respect to ownership, around $16 \%$ of the firms are independent, $27 \%$ belong to a domestic (Swedish) group, and 30\% are part of multinational groups with headquarter in Sweden. The bivariate correlations are rather low except among the different collaboration partner types as many firms do not only collaborate with one partner but 
several ones. Here, we obtain the highest collaboration between scientific partners and suppliers with a bivariate correlation coefficient of 0.68 .

\section{Econometric setup}

We apply in our main firm-level specifications Quasi-Maximum-Likelihood Poisson (QML-Poisson) regression models given the count-data nature of our dependent variables, which capture the number of skilled employees who leave the firm in a given year. In contrast to the standard Poisson model, the consistency of the QML-Poisson estimator does not rely on an underlying Poisson distribution of the data but is always consistent as long as the conditional mean is correctly specified (see Santos Silva and Tenreyo 2006). For implementing the QML-Poisson estimator and in order to consider that we observe many firms multiple times over time in our data, we cluster all standard errors by firms.

A concern in our research setting is the possibility that unobserved factors drive simultaneously firms' orientation towards research collaboration and employee exit decisions, resulting in endogeneity problems. For instance, lacking internal R\&D capabilities may lead to an increasing reliance of firms on external partners, while the same weaknesses may also imply an uncontent workforce and as a consequence, increasing mobility. In line with this concern, Garriga et al. (2013) showed that a stronger orientation towards Open Innovation is partially determined by firm-internal weaknesses. Furthermore, skilled employees may leave the firm for different reasons which remain unobserved, and the resulting scarcity of internal R\&D capabilities may force the firm to rely to a larger extent on external partners in order to achieve the desired goals. Therefore, both omitted variable bias and reverse causality problems may be prevalent. Ideally, we would use an instrumental variable which influences R\&D collaborations but is not related with unobserved factors that determine employee mobility. However, finding an instrument that is having a sufficiently high predictive power for collaboration while not exercising a direct influence towards the dependent variable is not straightforward in the context of Open Innovation and labor mobility. 
Therefore, we address corresponding concerns by including a comprehensive set of control variables, which is made possible thanks to our rich dataset. The control variables capture firm heterogeneity with respect to R\&D investment levels and financial performance, firms' workforce composition and worker compensation levels, ownership and location. For instance, lacking internal R\&D capabilities and a discontented workforce likely find expression in firms’ financial performance. By controlling for financial performance, we take indirectly unobserved mechanisms into account. Beyond our comprehensive set of standard controls, we also include the share of incoming $R \& D$ personnel of the previous year and the innovative performance as additional controls in a robustness test. The first additional measure is introduced based on the consideration that the observed employee mobility might be the result of incoming employees, which leads to a generally higher employee turnover rate. Including this measure results in a conservative estimation since it imposes the underlying assumption that incoming employees result in mobility and not vice versa. ${ }^{1}$ Moreover, we take advantage of the Panel structure of the dataset and estimate some regressions with firm-fixed effects by introducing the 5-year pre-sample mean of our dependent variables (see Blundell et al. 1999). However, it has to be kept in mind that firms' knowledge sourcing strategies tend to be very stable over time, potentially implying a considerable downward bias of our estimates given that a considerable part of the variation is removed.

\section{Regression results and discussion}

\section{Main specifications}

The main results of our econometric analysis are reported in Table 3. We report different specifications of our dependent variable, where we distinguish in the different columns between skilled workers who leave for employments in other firms and entrepreneurial exits. With regard to the independent variables, we first

\footnotetext{
${ }^{1}$ While the lag of one year may help to establish directionality, it is to consider that this variable does not show notable variation in the time dimension.
} 
introduce a dummy variable capturing the existence of at least one collaboration in columns (1a)-(1b), collaboration breadth which reflects the number of distinct partners for collaboration in columns (2a)-(2b), and finally decompose the different collaboration partner types in columns (3a)-(3b).

-- Insert Table 3 about here --

First, we introduce the dummy variable that captures the existence of at least one collaboration. We obtain a positive but non-significant effect for the dependent variables that measure the number of employees leaving for another firm (1a) or entrepreneurship (1b). The coefficient of the dummy variable can be interpreted as semielasticity (Cameron and Trivedi 2013), i.e. the discrete change from having no collaboration to collaboration implies a $13 \%$ increase in the rate of mobility at the mean values of our variables. However, given that the variable is not statistically significant, the pure existence of any kind of collaboration cannot be considered as a relevant determinant towards employee exits.

Once we take the extent of collaborative activities into account by introducing our measure collaboration breadth, we obtain positive and significant effects for the number of employee departures to other firms (2a) and entrepreneurial exits (2b) alike. One additional collaboration partner leads to a 7.1\% increase in mobility for the number of employees moving to other firms. However, the magnitude is considerably lower for employees starting entrepreneurial ventures, where we observe only a $4.3 \%$ increase. Therefore, we find support for our first two hypotheses, where we stated that an increasing reliance on external partners increases mobility (H1), and that the increase will be larger for inter-firm mobility (H2).

Finally, we shed light on potential heterogeneity with respect to the influence of different collaboration partners. As expected, we do not find a statistically significant effect for collaboration with academic institutions (H3a). In contrast to collaborations with other firms, partnerships with universities should not involve any pull effects, i.e. that the collaborating institutions tries to actively hire employees away. We 
also observe differences within different firm collaboration partners, i.e. suppliers, competitors, and users. Collaboration with competitors (H3b) is associated with a positive and significant impact towards mobility, and interestingly this result similarly holds for inter-firm mobility (3a) and employee entrepreneurship (3b). Whereas collaboration with competitors is in general considered being risky due to unavoidable knowledge exchanges, which may ultimately result in imitation, our results suggests that also the risk of employee mobility is increasing. Although with weaker magnitudes, also collaboration with users is associated with higher rates of employee mobility. On the other hand, collaboration with suppliers has a negative and statistically significant effect. Although it is not obvious why mobility is even reduced, it is, however, plausible that supplier collaboration has a different effect than partnerships with competitors. Between supply-chain partners, long-term considerations are of pivotal importance, potentially accompanied by relationship-specific investments, which may undermine incentives for active hiring away attempts between the involved firms.

\section{Heterogeneity analysis: firm size and manufacturing vs. service sectors}

In this section, we analyze whether the relationship between collaboration breadth and employee exits is subject to firm heterogeneity. First, we test whether the relationship differs for large vs. small firms as defined by the medium firm size in our sample (Table 4).

\section{-- Insert Table 4 about here -}

The econometric results show that the observed effect of mobility is predominantly driven by larger companies, where we obtain positive and significant effects for both dependent variable specifications. For smaller firms, collaboration breadth is not statistically significant and the sign of the coefficient becomes partially negative. Therefore, larger firms seem to be at higher risk that skilled employees leave as a result 
of firm openness. As a second heterogeneity test, we ran subsample regressions for manufacturing (1a)-(1b) and service sectors (2a)-(2b) and distinguish manufacturing firms by high-technology vs. low-technology ones (3a)-(4b) as reported in Table 5.

-- Insert Table 5 about here --

We obtain very similar results for manufacturing and service sectors. Our main variable of interest, collaboration breadth, is positive and significant for both subsamples, with very similar marginal effects. In line with our main regression results, we obtain slightly stronger magnitudes for employee mobility to other firms than for entrepreneurship. However, in contrast to service firms, collaboration breadth is statistically significant for explaining the amount of transitions to entrepreneurship in manufacturing firms. Finally, when we decompose manufacturing firms into high-technology and low-technology ones, we obtain only statistically significant effects for the high-technology context. Overall, these findings indicate that the relationship between firm openness as measured by research collaboration and mobility is not only a specific pattern that is only prevalent in some sectors but applies more broadly in knowledge-intensive settings.

\section{Individual-level analysis}

Our dataset also allows for providing complementary insights by executing an econometric analysis at the individual level. In particular, an individual-level analysis may take employee characteristics explicitly into account. From a managerial viewpoint, it would be particularly worrisome if employees with particularly high abilities are more likely to leave as a result of collaborative firm activities. In Table 6, we report Ordinary Least Square (OLS) regression results for a sample of employees with inter-firm mobility event and test whether the collaboration breadth of the previous firm co-determines the salary level at the new company. The salary level at the previous employer serves as a proxy for employee ability given that 
the salary should largely absorb all unobserved factors related to the employee's ability (see Campbell et al. 2012). Besides the general requirement of skilled employees, we focus in some specifications on a subset of employees who are having at least a master degree.

-- Insert Table 6 about here --

Not surprisingly, the previous salary-level strongly determines the salary level at the new employer. Without the interaction effect between collaboration breadth and the previous salary (Salary old employer), the collaboration breadth of the previous employer is not associated with a higher salary at the new employer (columns 1 and 2). However, once we introduce the interaction (3a)-(3b), we obtain a highly significant interaction effect. This result implies that highly qualified workers, as measured by their previous salary level, are able to realize higher salary levels at their new employers if the previous employers were engaged in research collaborations. At the same time, the collaboration breadth variable becomes significant and negative, i.e. workers with low salaries in the previous firm obtain on average lower salaries at the new employer if their old firm was collaborating for $\mathrm{R} \& \mathrm{D}$. Although we can only speculate about the underlying mechanisms behind this result for low ability employees, these regression results provide indirect support for the view that the risk of mobility as a result of R\&D collaboration is particularly pronounced for the most capable employees.

\section{Robustness tests}

We ran several additional regressions to assess the robustness of our results. First, we extend the list of control variables by adding the share of newly recruited employees in the prior year and by adding innovative sales in columns (1a)-(1b). The additional control mentioned first is included based on the consideration 
that employee departures are potentially caused by new incoming researchers as a result of explicit hiring attempts.

-- Insert Table 7 about here -

As one would expect, the share of incoming researchers is positive and highly significant. This is plausible given that the numbers of incoming and outgoing researchers are likely interrelated. However, we still observe a positive and significant effect of collaboration breadth on employee exits, which strongly supports the interpretation that openness augments the rate of departures. In other words, even if collaboration may facilitate hiring employees from other firms, there is on average still a "premium" of collaboration for employee departures. It has to be kept in mind that including this control variable leads to a rather restrictive estimation and likely underestimates the true impact, since the presence of the control variable in the regression implies that the number of incoming R\&D staff is causing employee departures, and not vice versa. Second, we limit our sample to firms that answered the CIS survey at least twice and control for firm-fixed effects by introducing the 5-year pre-sample mean of our dependent variables in the regression models as reported in columns (2a)-(2b). The pre-sample mean variable is positive and significant with respect to increasing departure rates. However, in addition, the collaboration breadth measure is still positive and significant for explaining the number of all leaving employees and inter-firm employee departures. Therefore, our results do not seem to be driven by time-invariant idiosyncratic firm characteristics. Third, we restricted the sample to firms where less than $50 \%$ of the employees leave in a given year (3a)-(3b). Firms with higher exit rates likely represent atypical cases due to bankruptcy or merger and acquisition events. The regression results are in line with our main models. 


\section{Conclusion}

This paper investigates the impact of firm openness, and in particular formal research collaboration, on employee mobility and entrepreneurship. Therefore, we provide new insights on micro-mechanisms related to the costs of open collaborative approaches for innovation. Our empirical analysis is conducted on a unique dataset which combines two data sources from Sweden, namely the Innovation survey (CIS) and the employee-employer register data. The results suggest that an increasing openness of firms leads to higher numbers of employees leaving the firm, and firm openness drives in particular inter-firm mobility rather than the creation of start-ups by employees. Moreover, different collaboration partners exercise heterogeneous impacts, with competitor collaboration having the highest magnitudes. Finally, by conducting a complementary analysis at the individual level, we obtained also first suggestive evidence that particularly high-ability employees generate valuable outside options.

Previous studies provided compelling evidence on positive performance effects of research collaboration and search for external knowledge more in general (Cassiman and Veugelers 2006; Laursen and Salter 2006). Whereas our results do not challenge the merits of openness per se, we provide micro-level evidence that specific costs can be associated with such a firm strategy, which may in certain circumstances outweigh the benefits. In this sense, the findings of our study are in line with the observation of Laursen and Salter (2006) that an overuse of external sources can result in diminishing returns. Our study suggests that an increasing labor mobility is one of the underlying drivers of this result.

Besides the immediate negative effect of losing highly capable employees as substitutes have to be hired or trained, mobility may also negatively affect the competitive position of firms. The recipient firms may be able to imitate technologies of the moving employee’s previous employer (e.g. Parotta and Pozzoli 2012; Palomeras and Melero 2010). As a consequence, firm managers have to consider carefully whether employee mobility is harmful both with regard to substitution costs and minimizing spillovers. In contexts where the spillover risk is high, for instance when formal intellectual property is of limited efficacy (see 
Kim and Marschke 2006; Agarwal et al. 2009), firms may be better off to rely more on internal knowledge creation capabilities. Similarly, if hiring new employees is challenging due to a scarcity of adequate candidates, or if extensive training is required, internal $R \& D$ is becoming comparatively more attractive.

Our study has several limitations. First, we cannot fully rule out endogeneity concerns since it was not feasible to implement an IV regression due to the absence of an appropriate instrumental variable. Therefore, we cannot interpret our findings as being causal. This limitation has to be kept in mind when interpreting our results. However, by introducing powerful control variables, which should largely absorb unobserved drivers of mobility, and by controlling for firm-fixed effects, we were able to demonstrate that the obtained correlation between openness and mobility is fairly robust. Second, we do not observe which of our employees are directly involved in a R\&D collaboration. However, conducting the analysis at the firm-yearlevel represents a rather conservative estimation given that many employees are presumably not directly involved in collaborative activities. 


\section{References}

Agarwal R., Audretsch D., 2001. Does entry size matter? The impact of the life cycle and technology on firm survival. Journal of Industrial Economics, 49(1), 21-43.

Agarwal R., Echambadi R., Franco, A., Sarkar, M., 2004. Knowledge transfer through inheritance: spinout generation, development and survival. Academy of Management Journal 47 (4), 501-522.

Agarwal R., Ganco M., Ziedonis, R.H., 2009. Reputations for toughness in patent enforcement. Implications for knowledge spillovers via inventor mobility. Strategic Management Journal 30, 13491374.

Alcacer J., Oxley, J., 2013. Learning by supplying. Strategic Management Journal 35(2), 204-223.

Barney, J., 1991. Firm resources and sustained competitive advantage. Journal of Management 17(1), 99120.

Belderbos, R., Carree, M., Lokshin, B., 2004. Cooperative R\&D and firm performance. Research Policy 33(10), 1477-1492.

Bidwell M., Keller, J.R., 2014. Within or without? How firms combine internal and external labor markets to fill jobs. Academy of Management Journal 57(4), 1035-1055.

Bloom, N., Schankerman M., Van Reenen J., 2013. Identifying technology spillovers and product market rivalry. Econometrica 81(4), 1347-1393.

Blyler, M., Coff, R.W. 2003. Dynamic capabilities, social capital, and rent appropriation: Ties that split pies. Strategic Management Journal 24, 677-686.

Blundell, R., Griffith, R., Van Reenen, J., 1999. Market share, market value and innovation in a panel of British manufacturing firms. Review of Economic Studies 66(3), 529-554.

Bouty, I., 2000. Interpersonal and interaction influences on informal resource exchanges between R\&D researchers across organizational boundaries. Academy of Management Journal 43(1), 50-65.

Cameron A.C., Trivedi, P.K., Regression Analysis of count data. Second edition, Cambridge University Press, Cambridge.

Campbell, B., Ganco M., Franco, A., Agrawal, R., 2012. Who leaves, where to, and why worry? Employee mobility, Entrepreneurship and effects on source firm performance. Strategic Management Journal 33, 65-87.

Campbell, B., Coff, R., Kryscynski, D., 2012: Re-thinking competitive advantage from human capital. Academy of Management Review 37(2), 376-395.

Carnahan S., Agarwal, R., Campbell, B., 2012: Heterogeneity in turnover: The effect of relative compensation dispersion of firms on the mobility and entrepreneurship of extreme performers. Strategic Management Journal 33, 1411-1430.

Cassiman, B., Veugelers, R., 2002. R\&D cooperation and spillovers: Some empirical evidence from Belgium. American Economic Review 92(4), 1169-1184.

Cassiman, B., Veugelers, R., 2006. In search of complementarity in innovation strategy: Internal R\&D and external knowledge acquisition. Management Science 52(1), 68-82.

Cassiman, B., Valentini G., 2015. Open Innovation: Are inbound and outbound knowledge flows really complementary? Strategic Management Journal 37 (6), 1034-1046.

Chatterji, A., Fabrizio K, 2014. Using users: when does external knowledge enhance corporate product innovation. Strategic Management Journal 35, 1427-1445. 
Chesbrough, H. 2003. Open Innovation - the new imperative for creating and profiting from technology. Harvard Business School Press, Boston.

Cockburn, I., Henderson, R., 1998. Absorptive capacity, coauthoring behavior, and the organization of research in drug discovery. Journal of Industrial Economics 46 (2), 157-182.

Coff, R., 1997. Human Assets and Management dilemmas: coping with hazards on the road to resourcebased theory. Academy of Management Review 22(2), 374-402.

Cooper D., 2001. Innovation and reciprocal externalities: information transmission via job mobility. Journal of Economic Behavior \& Organization 45, 403-425.

Corredoira, R.A., Rosenkopf, L., 2010. Should auld acquaintance be forgot? The reverse transfer of knowledge through mobility ties. Strategic Management Journal 31(2), 159-181.

Dahlander, L., Gann, D.M., 2010. How open is innovation? Research Policy 39(6), 699-709.

Elfenbein D.W., Hamilton B.H., Zenger, T.R., 2010. The small firm effect and the entrepreneurial spawning of scientists and engineers. Management Science 56(4), 659-681.

Fallick, B., Fleischman C.A., Rebitzer, J.B., 2006: Job hopping in Silicon Valley: some evidence concerning the micro-foundations of a high-technology cluster. Review of Economics and Statistics 88(3), 472-481.

Fleming, L., Sorensen, O., 2004. Science as a map in technological search. Strategic Management Journal 25(8-9), 909-928.

Fleming, L., Waguespack, D. M., 2007. Brokerage, Boundary spanning, and leadership in open innovation communities. Organization Science 18(2), 165-180.

Franco, A.M., Filson, D., 2006. Spin-outs: knowledge diffusion through employee mobility. RAND Journal of Economics 37(4), 841-860.

Franco, A.M., Mitchell, M.F., 2008. Covenants not to compete, labor mobility, and industry dynamics. Journal of Economics and Management Strategy 17(3), 581-606.

Gambardella A., Ganco M., Honoré, F., 2015. Using what you know: Patented knowledge in incumbent firms and employee entrepreneurship. Organization Science 26(2), 456-474.

Gambardella A., Panico, C., Valentini, G., 2015. Strategic incentives to human capital. Strategic Management Journal 36, 37-52.

Ganco, M. 2013. Cutting the Cordian knot: The effect of knowledge complexity on employee mobility and entrepreneurship. Strategic Management Journal 34, 666-686.

Ganco, M., Ziedonis, R.H., Agarwal, R., 2015. More stars stay, but the brightest ones still leave: job hopping in the shadow of patent enforcement. Strategic Management Journal 36, 659-685.

Garriga, H., Von Krogh, G., Spaeth, S., 2013. How constraints and knowledge impact open innovation. Strategic Management Journal 34, 1134-1144.

Giarratana, M.S., Mariani, M., 2014. The relationship between knowledge sourcing and fear of imitation. Strategic Management Journal 35, 1144-1163.

Gompers, P., Lerner, J., Scharfstein, D., 2005. Entrepreneurial spawning: public corporations and the genesis of new ventures 1986 to 1999. Journal of Finance 60(2), 577-614.

Grimpe, C., Kaiser, U., 2010. Balancing internal and external knowledge acquisition: the gains and pains from R\&D outsourcing. Journal of Management Studies 47(8), 1483-1509. 
Gruber, M., Harhoff D., Hoisl, K., 2013. Knowledge recombination across technological boundaries: Scientists vs. Engineers. Management Science 59(4), 837-851.

Hagedoorn J., 1993. Understanding the rationale of strategic technology partnering: Interorganizational modes of cooperation and sectoral differences. Strategic Management Journal 14, 371-385.

Hamel, G., Doz, Y.L., Prahalad, C.K., 1989. Collaborate with your competitors - and win. Harvard Business Review, Jan-Feb 1989.

Hatch, N.W., Dyer, J.H., 2004. Human capital and learning as a source of sustainable competitive advantage. Strategic Management Journal 25(12), 1155-1178.

Hatzichronoglou, T., 1997. Revision of the High-Technology Sector and Product classification. OECD Science, Technology and Industry Working Papers No. 1997/02.

Hellmann, T., 2007. When do employees become entrepreneurs? Management Science 53(6), 919-933.

Isaksson, O., Simeth, M., Seifert R., 2016. Knowledge spillovers in the supply chain: Evidence from the high tech sectors. Research Policy 45(3), 699-706.

Kaiser, U., Kongsted H.C., Ronde, T., 2015. Does the mobility of R\&D labor increase innovation. Journal of Economic Behavior \& Organization 110, 91-105.

Katila, R., Ahuja, G., 2002. Something old, something new: A longitudinal study of search behavior and new product introduction. Academy of Management Journal 45 (6), 1183-1194.

Kim, J., Marschke, G., 2005. Labor mobility of scientists, technological diffusion, and the firm's patenting decision. RAND Journal of Economics 36 (2), 298-317.

Klepper, S., Thompson, P., 2010. Disagreements and intra-industry spinoffs. International Journal of Industrial Organization 28, 526-538.

Kotabe, M., Martin, X., Domoto, H., 2002. Gaining from vertical partnerships: knowledge transfer, relationship duration, and supplier performance improvement in the U.S. and Japanese automotive industries. Strategic Management Journal 24(4), 293-316.

Laursen, K., Salter, A., 2006. Open for innovation: The role of openness in explaining innovation performance among U.K. manufacturing firms. Strategic Management Journal 27(2) 131-150.

Levin, R.C., Klevorick A.K., Nelson R.R., Winter S.G., Gilbert R., Griliches Z., 1987. Appropriating the returns from Industrial Research and Development. Brookings Papers on Economic Activity 1987(3), 783-831.

Liu C., Stuart T., 2011. Boundary spanning in a for-profit research lab: An exploration of the interface between Commerce and Academe. Working Paper.

Maliranta, M., Mohnen, P., Rouvinen, P., 2009. Is Inter-firm labor mobility a channel of knowledge spillovers? Evidence from a linked employer-employee panel. Industrial and Corporate Change 18(6), 1161-1191

Marx, M., Strumsky, D., Fleming, L., 2009. Mobility, skills, and the Michigan non-compete experiment. Management Science 55(6), 875-889.

Mohammadi, A., Broström A., Franzoni, C., 2016. Workforce composition and innovation: how diversity in employees' ethnic and educational backgrounds facilitates firm-level innovativeness. Journal of Product Innovation Management (forthcoming).

Oyer, P., Schaefer, S., 2010. Personnel Economics: Hiring and incentives. NBER Working Paper No.15977. 
Palomeras N., Melero, E., 2010. Market for inventors: Learning by hiring as a driver of mobility. Management Science 56 (5), 881-895.

Parrotta, P., Pozzoli, D., 2012. The effect of learning by hiring on productivity. RAND Journal of Economics 43(1), 167-185.

Powell, W., Koput, K.W., Smith-Doerr, L., 1996. Interorganizational collaboration and the locus of innovation: Networks of learning in biotechnology. Administrative Science Quarterly 41 (1), 116-145.

Rosenkopf, L., Almeida, P., 2003. Overcoming local search through alliances and mobility. Management Science 49(6), 751-766.

Rosenkopf, L., Nerkar, A., 2001. Beyond local search: Boundary-spanning, exploration, and impact in the optical disk industry. Strategic Management Journal 22, 287-306.

Samila, S., Sorenson, O., 2011. Non-compete covenants: incentives to innovate or impediments to growth. Management Science 57(3), 425-438.

Santos Silva, J.M.C., Tenreyo, S., 2006. The Log of Gravity. Review of Economics and Statistics 88(4), 641-658.

Sheridan, J.E., 1992. Organizational Culture and Employee Retention. Academy of Management Journal 35, 1036-1056.

Singh, J., Agrawal, A., 2011. Recruiting for ideas: how firms exploit the prior inventions of new hires. Management Science 57(1), 129-150.

Song, J., Almeida, P., Wu, G., 2003. Learning-by-hiring: when is mobility more likely to facilitate interfirm knowledge transfer? Management Science 49(4), 351-365.

Spence M., 1973. Job market signaling. Quarterly Journal of Economics 87(3), 355-374.

Stephan, P., 2012. How Economics shapes science. Harvard University Press, Boston.

Toivanen, O., Väänänen, L., 2012. Returns to Inventors. Review of Economics and Statistics 94(4), 11731190.

Wezel, F.C., Cattani, G., Pennings, J.M., 2006. Competitive implications of interfirm mobility. Organization Science 17(6), 691-709.

Williams, C.R., Livingstone, L.P., 1994. Another look at the relationship between performance and voluntary turnover. Academy of Management Journal 37(2), 269-298.

Zenger, T.R., 1992. Why do employers only reward extreme performance? Examining the relationships among performance, pay, and turnover. Administrative Science Quarterly 37(2),198-219. 
Table 1: Descriptive statistics

\begin{tabular}{lcccc}
\hline Variable & Mean & S.D. & Min & Max \\
\hline Entrepreneurship & 0.643 & 2.632 & 0 & 75 \\
Inter-firm mobility & 9.267 & 45.373 & 0 & 1797 \\
Collaboration & 0.497 & 0.5 & 0 & 1 \\
Collaboration Breadth & 1.541 & 1.768 & 0 & 5 \\
Supplier collaboration & 0.399 & 0.49 & 0 & 1 \\
Customer collaboration & 0.267 & 0.443 & 0 & 1 \\
Competitor collaboration & 0.182 & 0.386 & 0 & 1 \\
Academic collaboration & 0.388 & 0.487 & 0 & 1 \\
Avg salary (in logs) & 12.936 & 0.27 & 7.056 & 16.05 \\
Salary standard dev & 0.439 & 0.193 & 0 & 2.463 \\
Women share & 0.251 & 0.189 & 0 & 1 \\
PhD share & 0.02 & 0.066 & 0 & 1 \\
R\&D intensity (in logs) & 0.082 & 0.279 & 0 & 4.156 \\
ROA & 0.038 & 0.288 & -13.808 & 9.296 \\
Firm size (in logs) & 4.201 & 1.44 & 2.398 & 10.457 \\
Young firm & 0.364 & 0.481 & 0 & 1 \\
Independent & 0.161 & 0.368 & 0 & 1 \\
Domestic group & 0.271 & 0.444 & 0 & 1 \\
Domestic Multinationals & 0.297 & 0.457 & 0 & 1 \\
\hline & & & &
\end{tabular}




\section{Table 2: Bivariate correlations}

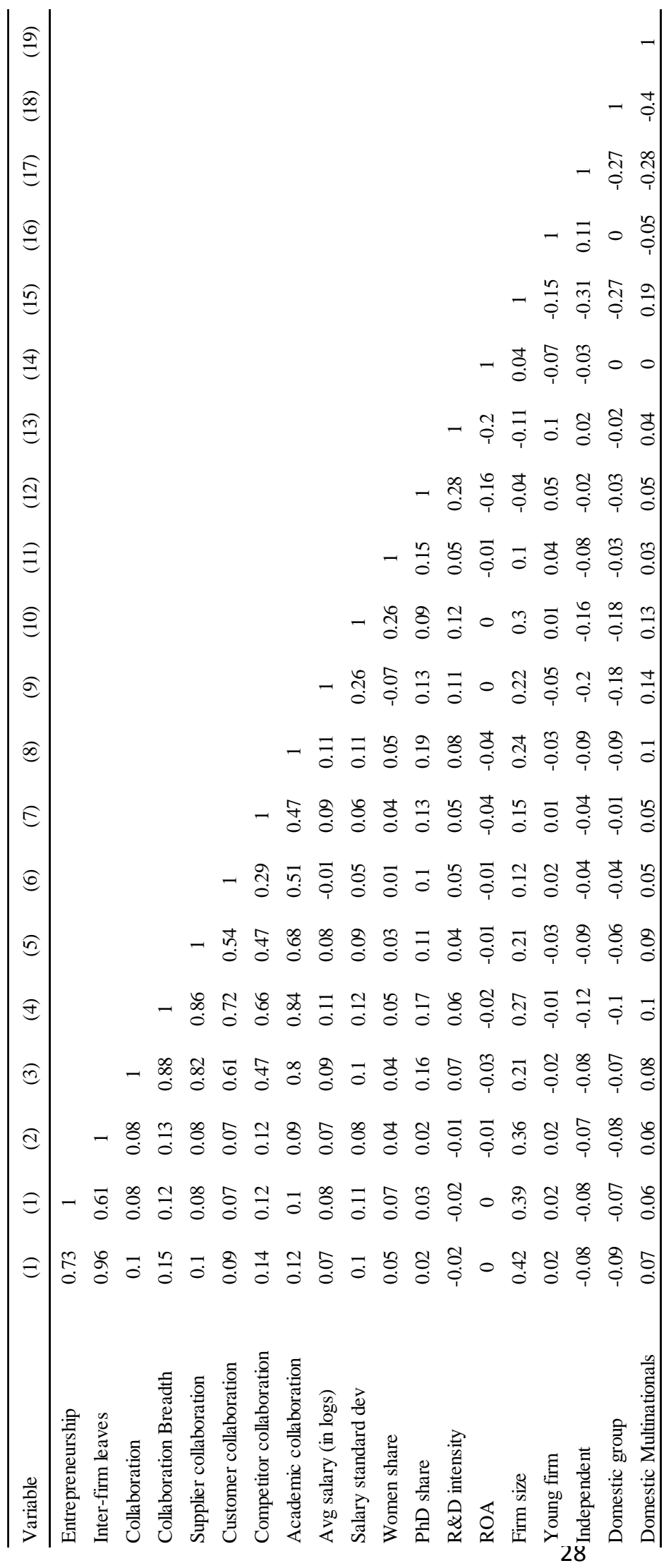


Table 3: Main regression results

\begin{tabular}{|c|c|c|c|c|c|c|}
\hline & $\begin{array}{c}\text { (1a) } \\
\text { Inter-firm mobility } \\
\text { coeff (S.E) }\end{array}$ & $\begin{array}{c}\text { (1b) } \\
\text { Entrepreneurship } \\
\text { coeff (S.E) }\end{array}$ & $\begin{array}{c}(2 \mathrm{a}) \\
\text { Inter-firm mobility } \\
\text { coeff (S.E) }\end{array}$ & $\begin{array}{c}\text { (2b) } \\
\text { Entrepreneurship } \\
\text { coeff (S.E) }\end{array}$ & $\begin{array}{c}\text { (3a) } \\
\text { Inter-firm mobilty } \\
\text { coeff (S.E) }\end{array}$ & $\begin{array}{c}\text { (3b) } \\
\text { Entrepreneurship } \\
\text { coeff (S.E) }\end{array}$ \\
\hline Collaboration (1/0) & $\begin{array}{c}0.132 \\
(0.085)\end{array}$ & $\begin{array}{c}0.053 \\
(0.069)\end{array}$ & & & & \\
\hline Collaboration Breadth & & & $\begin{array}{c}0.071^{* * *} \\
(0.021)\end{array}$ & $\begin{array}{l}0.043^{* *} \\
(0.019)\end{array}$ & & \\
\hline Supplier collaboration (1/0) & & & & & $\begin{array}{l}-0.299 * \\
(0.162)\end{array}$ & $\begin{array}{c}-0.234^{* * *} \\
(0.090)\end{array}$ \\
\hline Customer collaboration $(1 / 0)$ & & & & & $\begin{array}{l}0.223 * * \\
(0.096)\end{array}$ & $\begin{array}{c}0.066 \\
(0.100)\end{array}$ \\
\hline Competitor collaboration (1/0) & & & & & $\begin{array}{c}0.355^{* * *} \\
(0.112)\end{array}$ & $\begin{array}{c}0.299 * * * \\
(0.094)\end{array}$ \\
\hline Academic collaboration (1/0) & & & & & $\begin{array}{l}-0.088 \\
(0.172)\end{array}$ & $\begin{array}{c}0.024 \\
(0.084)\end{array}$ \\
\hline Avg salary (in logs) & $\begin{array}{c}0.119 \\
(0.236)\end{array}$ & $\begin{array}{c}0.243 \\
(0.217)\end{array}$ & $\begin{array}{c}0.071 \\
(0.230)\end{array}$ & $\begin{array}{c}0.215 \\
(0.210)\end{array}$ & $\begin{array}{c}0.048 \\
(0.215)\end{array}$ & $\begin{array}{c}0.213 \\
(0.203)\end{array}$ \\
\hline Salary standard dev & $\begin{array}{c}-0.933^{* * *} \\
(0.289)\end{array}$ & $\begin{array}{l}-0.494 \\
(0.302)\end{array}$ & $\begin{array}{c}-0.903^{* * *} \\
(0.275)\end{array}$ & $\begin{array}{l}-0.479 \\
(0.294)\end{array}$ & $\begin{array}{c}-0.893 * * * \\
(0.255)\end{array}$ & $\begin{array}{l}-0.500^{*} \\
(0.285)\end{array}$ \\
\hline R\&D intensity & $\begin{array}{c}0.148 \\
(0.144)\end{array}$ & $\begin{array}{l}-0.083 \\
(0.108)\end{array}$ & $\begin{array}{c}0.149 \\
(0.145)\end{array}$ & $\begin{array}{l}-0.083 \\
(0.110)\end{array}$ & $\begin{array}{c}0.153 \\
(0.150)\end{array}$ & $\begin{array}{l}-0.084 \\
(0.109)\end{array}$ \\
\hline ROA & $\begin{array}{c}-0.176^{* * *} \\
(0.063)\end{array}$ & $\begin{array}{c}-0.160^{* *} \\
(0.065)\end{array}$ & $\begin{array}{c}-0.180 * * * \\
(0.063)\end{array}$ & $\begin{array}{c}-0.162 * * \\
(0.065)\end{array}$ & $\begin{array}{c}-0.188 * * * \\
(0.062)\end{array}$ & $\begin{array}{c}-0.160^{* *} \\
(0.065)\end{array}$ \\
\hline Firm size & $\begin{array}{c}0.878 * * * \\
(0.032)\end{array}$ & $\begin{array}{c}0.791 * * * \\
(0.037)\end{array}$ & $\begin{array}{c}0.860^{* * *} \\
(0.030)\end{array}$ & $\begin{array}{c}0.779 * * * \\
(0.034)\end{array}$ & $\begin{array}{c}0.858^{* * *} \\
(0.027)\end{array}$ & $\begin{array}{c}0.774^{* * *} \\
(0.032)\end{array}$ \\
\hline $\begin{array}{l}\text { Further firm-level controls } \\
\text { Industry fixed effects } \\
\text { Year fixed effects }\end{array}$ & $\begin{array}{l}\text { Yes } \\
\text { Yes } \\
\text { Yes }\end{array}$ & $\begin{array}{l}\text { Yes } \\
\text { Yes } \\
\text { Yes }\end{array}$ & $\begin{array}{l}\text { Yes } \\
\text { Yes } \\
\text { Yes }\end{array}$ & $\begin{array}{l}\text { Yes } \\
\text { Yes } \\
\text { Yes }\end{array}$ & $\begin{array}{l}\text { Yes } \\
\text { Yes } \\
\text { Yes }\end{array}$ & $\begin{array}{l}\text { Yes } \\
\text { Yes } \\
\text { Yes }\end{array}$ \\
\hline $\begin{array}{l}\text { Observations } \\
\text { Number firms } \\
\text { Log lik. }\end{array}$ & $\begin{array}{c}8012 \\
4608 \\
-52052.0\end{array}$ & $\begin{array}{c}8012 \\
4608 \\
-7197.8 \\
\end{array}$ & $\begin{array}{c}8012 \\
4608 \\
-51645.7\end{array}$ & $\begin{array}{c}8012 \\
4608 \\
-7185.7 \\
\end{array}$ & $\begin{array}{c}8012 \\
4608 \\
-50649.2\end{array}$ & $\begin{array}{c}8012 \\
4608 \\
-7149.7 \\
\end{array}$ \\
\hline
\end{tabular}

Standard errors clustered by firm. $* * * \mathrm{p}<0.01, * * \mathrm{p}<0.05, * \mathrm{p}<0.1$

Table report the results of QML-Poisson regression models. All regressions contain further firm-level control variables: Women share, $\mathrm{PhD}$ share, independent firm, domestic group, young firm. Regressions 3a-3b also contain a dummy for Internal collaboration. 
Table 4: Firm size heterogeneity

\begin{tabular}{|c|c|c|c|c|}
\hline & (1a) & (1b) & $(2 a)$ & (2b) \\
\hline & \multicolumn{2}{|c|}{ Size above median } & \multicolumn{2}{|c|}{ Size below median } \\
\hline & Inter-firm mobility & Entrepreneurship & Inter-firm mobilty & Entrepreneurship \\
\hline & coeff (S.E) & coeff (S.E) & coeff (S.E) & coeff (S.E) \\
\hline \multirow[t]{2}{*}{ Collaboration Breadth } & $0.078 * * *$ & $0.045^{* *}$ & -0.029 & -0.001 \\
\hline & $(0.023)$ & $(0.021)$ & $(0.018)$ & $(0.032)$ \\
\hline \multirow[t]{2}{*}{ Avg salary (in logs) } & 0.080 & 0.273 & 0.035 & 0.018 \\
\hline & $(0.262)$ & $(0.242)$ & $(0.102)$ & $(0.169)$ \\
\hline \multirow[t]{2}{*}{ Salary standard dev } & $-1.001 * * *$ & $-0.690 * *$ & $0.630 * * *$ & $0.916^{* * *}$ \\
\hline & $(0.299)$ & $(0.331)$ & $(0.116)$ & $(0.202)$ \\
\hline \multirow[t]{2}{*}{ Women share } & -0.113 & $0.938 * * *$ & 0.029 & -0.131 \\
\hline & $(0.311)$ & $(0.333)$ & $(0.147)$ & $(0.249)$ \\
\hline \multirow[t]{2}{*}{ PhD share } & 0.804 & 0.524 & -0.162 & $-1.030 *$ \\
\hline & $(0.962)$ & (1.106) & $(0.390)$ & $(0.597)$ \\
\hline \multirow[t]{2}{*}{ R\&D intensity } & 0.143 & -0.184 & -0.002 & 0.039 \\
\hline & $(0.175)$ & $(0.171)$ & $(0.097)$ & $(0.119)$ \\
\hline \multirow[t]{2}{*}{ ROA } & $-0.384 * *$ & $-0.278^{*}$ & $-0.141^{* * *}$ & $-0.157 * *$ \\
\hline & $(0.156)$ & $(0.145)$ & $(0.031)$ & $(0.067)$ \\
\hline \multirow[t]{2}{*}{ Firm size } & $0.849 * * *$ & $0.794 * * *$ & $0.768 * * *$ & $0.435 * * *$ \\
\hline & $(0.035)$ & $(0.041)$ & $(0.068)$ & (0.118) \\
\hline Further firm-level controls & Yes & Yes & Yes & Yes \\
\hline Industry fixed effects & Yes & Yes & Yes & Yes \\
\hline Year fixed effects & Yes & Yes & Yes & Yes \\
\hline Observations & 4088 & 4088 & 3924 & 3924 \\
\hline Number firms & 2128 & 2128 & 2676 & 2676 \\
\hline Log lik. & -44054.1 & -5499.9 & -6817.5 & -1605.5 \\
\hline
\end{tabular}

Standard errors clustered by firm. *** $\mathrm{p}<0.01,{ }^{* *} \mathrm{p}<0.05,{ }^{*} \mathrm{p}<0.1$

Table report the results of QML-Poisson regression models. All regressions contain further firm-level control variables: Women share, $\mathrm{PhD}$ share, independent firm, domestic group, young firm. Regressions 3a-3b also contain a dummy for Internal collaboration. 
Table 5: Manufacturing vs. Service sectors

\begin{tabular}{|c|c|c|c|c|c|c|c|c|}
\hline & (1a) & (1b) & (2a) & (2b) & (3a) & (3b) & (4a) & (4b) \\
\hline & \multicolumn{2}{|c|}{ Manufacturing } & \multicolumn{2}{|c|}{ Services } & \multicolumn{2}{|c|}{ High Tech Manufacturing } & \multicolumn{2}{|c|}{ Low Tech Manufacturing } \\
\hline & $\begin{array}{c}\text { Inter-firm mobility } \\
\text { coeff (S.E) }\end{array}$ & $\begin{array}{c}\text { Entrepreneurship } \\
\text { coeff (S.E) }\end{array}$ & $\begin{array}{c}\text { Inter-firm mobility } \\
\text { coeff (S.E) }\end{array}$ & $\begin{array}{c}\text { Entrepreneurship } \\
\text { coeff (S.E) }\end{array}$ & $\begin{array}{c}\text { Inter-firm mobility } \\
\text { coeff (S.E) }\end{array}$ & $\begin{array}{c}\text { Entrepreneurship } \\
\text { coeff (S.E) }\end{array}$ & $\begin{array}{c}\text { Inter-firm mobility } \\
\text { coeff (S.E) }\end{array}$ & $\begin{array}{c}\text { Entrepreneurship } \\
\text { coeff (S.E) }\end{array}$ \\
\hline Collaboration Breadth & $\begin{array}{l}0.052 * * \\
(0.023)\end{array}$ & $\begin{array}{l}0.042^{* *} \\
(0.019)\end{array}$ & $\begin{array}{l}0.065^{* *} \\
(0.030)\end{array}$ & $\begin{array}{c}0.031 \\
(0.023)\end{array}$ & $\begin{array}{l}0.065^{* *} \\
(0.028)\end{array}$ & $\begin{array}{l}0.047 * \\
(0.028)\end{array}$ & $\begin{array}{c}0.026 \\
(0.027)\end{array}$ & $\begin{array}{c}0.038 \\
(0.044)\end{array}$ \\
\hline Avg salary (in logs) & $\begin{array}{l}-0.107 \\
(0.318)\end{array}$ & $\begin{array}{l}-0.061 \\
(0.318)\end{array}$ & $\begin{array}{l}-0.187 \\
(0.268)\end{array}$ & $\begin{array}{c}0.121 \\
(0.221)\end{array}$ & $\begin{array}{c}0.150 \\
(0.551)\end{array}$ & $\begin{array}{l}1.072 * * \\
(0.504)\end{array}$ & $\begin{array}{c}-0.910^{* * *} \\
(0.283)\end{array}$ & $\begin{array}{l}-0.283 \\
(0.313)\end{array}$ \\
\hline Salary standard dev & $\begin{array}{c}-0.675^{* * *} \\
(0.253)\end{array}$ & $\begin{array}{l}-0.068 \\
(0.274)\end{array}$ & $\begin{array}{l}-0.527 \\
(0.322)\end{array}$ & $\begin{array}{l}-0.272 \\
(0.291)\end{array}$ & $\begin{array}{c}-0.786^{* * *} \\
(0.224)\end{array}$ & $\begin{array}{l}-0.203 \\
(0.376)\end{array}$ & $\begin{array}{c}0.293 \\
(0.287)\end{array}$ & $\begin{array}{l}-0.267 \\
(0.512)\end{array}$ \\
\hline R\&D intensity & $\begin{array}{l}-0.022 \\
(0.129)\end{array}$ & $\begin{array}{l}-0.203 \\
(0.138)\end{array}$ & $\begin{array}{c}0.216 \\
(0.193)\end{array}$ & $\begin{array}{l}-0.009 \\
(0.121)\end{array}$ & $\begin{array}{l}-0.200 \\
(0.382)\end{array}$ & $\begin{array}{l}-0.132 \\
(0.307)\end{array}$ & $\begin{array}{l}-0.168 \\
(0.168)\end{array}$ & $\begin{array}{l}-0.008 \\
(0.126)\end{array}$ \\
\hline ROA & $\begin{array}{c}-0.978^{* * *} \\
(0.207)\end{array}$ & $\begin{array}{c}-0.562^{* * *} \\
(0.192)\end{array}$ & $\begin{array}{c}-0.132 * * \\
(0.057)\end{array}$ & $\begin{array}{c}-0.159 * * \\
(0.064)\end{array}$ & $\begin{array}{c}-0.865^{* * *} \\
(0.238)\end{array}$ & $\begin{array}{c}-0.612^{* *} \\
(0.247)\end{array}$ & $\begin{array}{c}-0.587 * * \\
(0.247)\end{array}$ & $\begin{array}{c}-1.663^{* * *} \\
(0.455)\end{array}$ \\
\hline Firm size & $\begin{array}{c}0.871^{* * *} \\
(0.026)\end{array}$ & $\begin{array}{c}0.842^{* * *} \\
(0.025)\end{array}$ & $\begin{array}{c}0.835^{* * *} \\
(0.040)\end{array}$ & $\begin{array}{c}0.712 * * * \\
(0.032)\end{array}$ & $\begin{array}{c}0.858 * * * \\
(0.029)\end{array}$ & $\begin{array}{c}0.844 * * * \\
(0.029)\end{array}$ & $\begin{array}{c}0.782^{* * *} \\
(0.055)\end{array}$ & $\begin{array}{c}0.848^{* * *} \\
(0.064)\end{array}$ \\
\hline Young firm & $\begin{array}{c}0.049 \\
(0.145)\end{array}$ & $\begin{array}{c}0.061 \\
(0.091)\end{array}$ & $\begin{array}{l}0.306^{* *} \\
(0.125)\end{array}$ & $\begin{array}{c}0.080 \\
(0.089)\end{array}$ & $\begin{array}{c}0.214 \\
(0.200)\end{array}$ & $\begin{array}{c}0.112 \\
(0.119)\end{array}$ & $\begin{array}{l}-0.037 \\
(0.123)\end{array}$ & $\begin{array}{c}-0.316^{*} \\
(0.185)\end{array}$ \\
\hline Further firm-level controls & Yes & Yes & Yes & Yes & Yes & Yes & Yes & Yes \\
\hline Industry fixed effects & Yes & Yes & Yes & Yes & Yes & Yes & Yes & Yes \\
\hline Year fixed effects & Yes & Yes & Yes & Yes & Yes & Yes & Yes & Yes \\
\hline Observations & 4946 & 4946 & 3066 & 3066 & 2156 & 2156 & 2790 & 2790 \\
\hline Number firms & 2598 & 2598 & 2091 & 2091 & 1106 & 1106 & 1596 & 1596 \\
\hline Log lik. & -24066.6 & -3374.8 & -21615.0 & -3283.2 & -11579.7 & -1663.7 & -1673.0 & -12053.6 \\
\hline
\end{tabular}

Standard errors clustered by firm. ${ }^{* * *} \mathrm{p}<0.01,{ }^{* *} \mathrm{p}<0.05,{ }^{*} \mathrm{p}<0.1$

Table report the results of QML-Poisson regression models. All regressions contain further firm-level control variables: Women share, $\mathrm{PhD}$ share, independent firm, domestic group, young firm. 
Table 6: Individual-level analysis

\begin{tabular}{|c|c|c|c|c|c|c|}
\hline & $\begin{array}{c}\text { (1a) } \\
\text { Log New Salary } \\
\text { coeff (S.E) }\end{array}$ & $\begin{array}{c}\text { (1b) } \\
\text { Log New Salary } \\
\text { coeff (S.E) }\end{array}$ & $\begin{array}{c}\text { (2a) } \\
\text { Log New Salary } \\
\text { coeff (S.E) }\end{array}$ & $\begin{array}{c}(2 b) \\
\text { Log New Salary } \\
\text { coeff (S.E) }\end{array}$ & $\begin{array}{c}\text { (3a) } \\
\text { Log New Salary } \\
\text { coeff (S.E) }\end{array}$ & $\begin{array}{c}\text { (3b) } \\
\text { Log New Salary } \\
\text { coeff (S.E) }\end{array}$ \\
\hline Collaboration breadth & $\begin{array}{l}-0.002 \\
(0.002)\end{array}$ & $\begin{array}{l}-0.002 \\
(0.003)\end{array}$ & $\begin{array}{l}-0.002 \\
(0.002)\end{array}$ & $\begin{array}{c}0.000 \\
(0.004)\end{array}$ & $\begin{array}{c}-0.268 * * * \\
(0.071)\end{array}$ & $\begin{array}{c}-0.443 * * * \\
(0.085)\end{array}$ \\
\hline Salary old employer (in logs) & $\begin{array}{c}0.566 * * * \\
(0.010)\end{array}$ & $\begin{array}{c}0.493 * * * \\
(0.015)\end{array}$ & $\begin{array}{c}0.546^{* * *} \\
(0.010)\end{array}$ & $\begin{array}{c}0.486^{* * *} \\
(0.015)\end{array}$ & $\begin{array}{c}0.487 * * * \\
(0.017)\end{array}$ & $\begin{array}{c}0.385^{* * *} \\
(0.025)\end{array}$ \\
\hline Collab breadth X Salary old & & & & & $\begin{array}{c}0.021^{* * *} \\
(0.005)\end{array}$ & $\begin{array}{c}0.034^{* * *} \\
(0.007)\end{array}$ \\
\hline $\begin{array}{l}\text { Firm-level controls } \\
\text { Firm-fixed effects } \\
\text { Industry fixed effects } \\
\text { Year fixed effects }\end{array}$ & $\begin{array}{l}\text { Yes } \\
\text { No } \\
\text { Yes } \\
\text { Yes }\end{array}$ & $\begin{array}{l}\text { Yes } \\
\text { No } \\
\text { Yes } \\
\text { Yes }\end{array}$ & $\begin{array}{l}\text { Yes } \\
\text { Yes } \\
\text { Yes } \\
\text { Yes }\end{array}$ & $\begin{array}{l}\text { Yes } \\
\text { Yes } \\
\text { Yes } \\
\text { Yes }\end{array}$ & $\begin{array}{l}\text { Yes } \\
\text { Yes } \\
\text { Yes } \\
\text { Yes }\end{array}$ & $\begin{array}{l}\text { Yes } \\
\text { Yes } \\
\text { Yes } \\
\text { Yes }\end{array}$ \\
\hline $\begin{array}{l}\text { Observations } \\
\text { Number firms } \\
\text { Log lik. }\end{array}$ & $\begin{array}{c}54491 \\
1532 \\
-25475.7\end{array}$ & $\begin{array}{c}14863 \\
941 \\
-7086.0\end{array}$ & $\begin{array}{c}54491 \\
1532 \\
-23787.2\end{array}$ & $\begin{array}{c}15183 \\
972 \\
-6529.3\end{array}$ & $\begin{array}{c}54491 \\
1532 \\
-23689.8\end{array}$ & $\begin{array}{c}15183 \\
972 \\
-6451.4\end{array}$ \\
\hline
\end{tabular}

Standard errors clustered by firm. ${ }^{* * *} \mathrm{p}<0.01,{ }^{* *} \mathrm{p}<0.05,{ }^{*} \mathrm{p}<0.1$

Table reports OLS regression results. Columns of type (a) report results when all employees in skilled labour are considered, columns of (b) are restricted to employees who have at least a masters degree. Firm-level variables include: R\&D intensity, Firm size, Average Salary level, Women share, PhD share,

independent firm, domestic group, young firm. Columns (1) is a baseline regression without firm-fixed effects. Column (2) show results including firm-fixed

effects, Column (3) contains interaction between Collaboration Breadth and the salary of the employee at the previous firm. 


\section{Table 7: Robustness tests}

\begin{tabular}{|c|c|c|c|c|c|c|}
\hline & (1a) & (1b) & (2a) & (2b) & (3a) & (3b) \\
\hline & Inter-firm mobility & Entrepreneurship & Inter-firm mobility & Entrepreneurship & Inter-firm mobility & Entrepreneurship \\
\hline & QML-P & QML-P & QML-P & QML-P & QML-P & QML-P \\
\hline & coeff (S.E) & coeff (S.E) & coeff (S.E) & coeff (S.E) & coeff (S.E) & coeff (S.E) \\
\hline \multirow[t]{2}{*}{ Collaboration Breadth } & $0.029 *$ & $0.062 * * *$ & $0.061^{* *}$ & -0.003 & $0.048^{* * *}$ & 0.030 \\
\hline & $(0.017)$ & $(0.020)$ & $(0.026)$ & $(0.018)$ & $(0.018)$ & $(0.021)$ \\
\hline \multirow[t]{2}{*}{ Share incoming employees } & $2.203^{* * *}$ & $1.946^{* * *}$ & & & & \\
\hline & $(0.489)$ & $(0.642)$ & & & & \\
\hline \multirow[t]{2}{*}{ Innovative Sales } & $0.705^{* * *}$ & $0.563^{* * *}$ & & & & \\
\hline & $(0.130)$ & $(0.162)$ & & & & \\
\hline \multirow[t]{2}{*}{ Pre-sample mean $D V$} & & & $0.002^{* * *}$ & $0.028 * * *$ & & \\
\hline & & & $(0.000)$ & $(0.004)$ & & \\
\hline Further firm-level controls & Yes & Yes & Yes & Yes & Yes & Yes \\
\hline Industry fixed effects & Yes & Yes & Yes & Yes & Yes & Yes \\
\hline Year fixed effects & Yes & Yes & Yes & Yes & Yes & Yes \\
\hline Observations & 8012 & 8012 & 4924 & 4924 & 7477 & 7477 \\
\hline Number firms & 4608 & 4608 & 2015 & 2015 & 4273 & 4273 \\
\hline Log lik. & -7083.2 & -50669.6 & -29894.5 & -4438.1 & -33918.0 & -6817.4 \\
\hline
\end{tabular}

Standard errors clustered by firm. ${ }^{* * *} \mathrm{p}<0.01,{ }^{* *} \mathrm{p}<0.05,{ }^{*} \mathrm{p}<0.1$

Table report the results of QML-Poisson regression models. Columns (1) show regression results with the additional control variables Share incoming researchers and Innovative Sales. Columns (2) represent regression results that include as an additional control variable the pre-sample mean of the dependent variable in order to control for firm-fixed effects. Columns (3) show regression results for a subsample of firms where the share of leaving employees is less than $50 \%$.

Further firm-level control variables include: R\&D intensity (in logs), Firm size (in logs), Average salary level (in logs), ROA, Young firm, Women share, PhD share, independent firm, domestic group. 
Figure 1: Collaboration Breadth

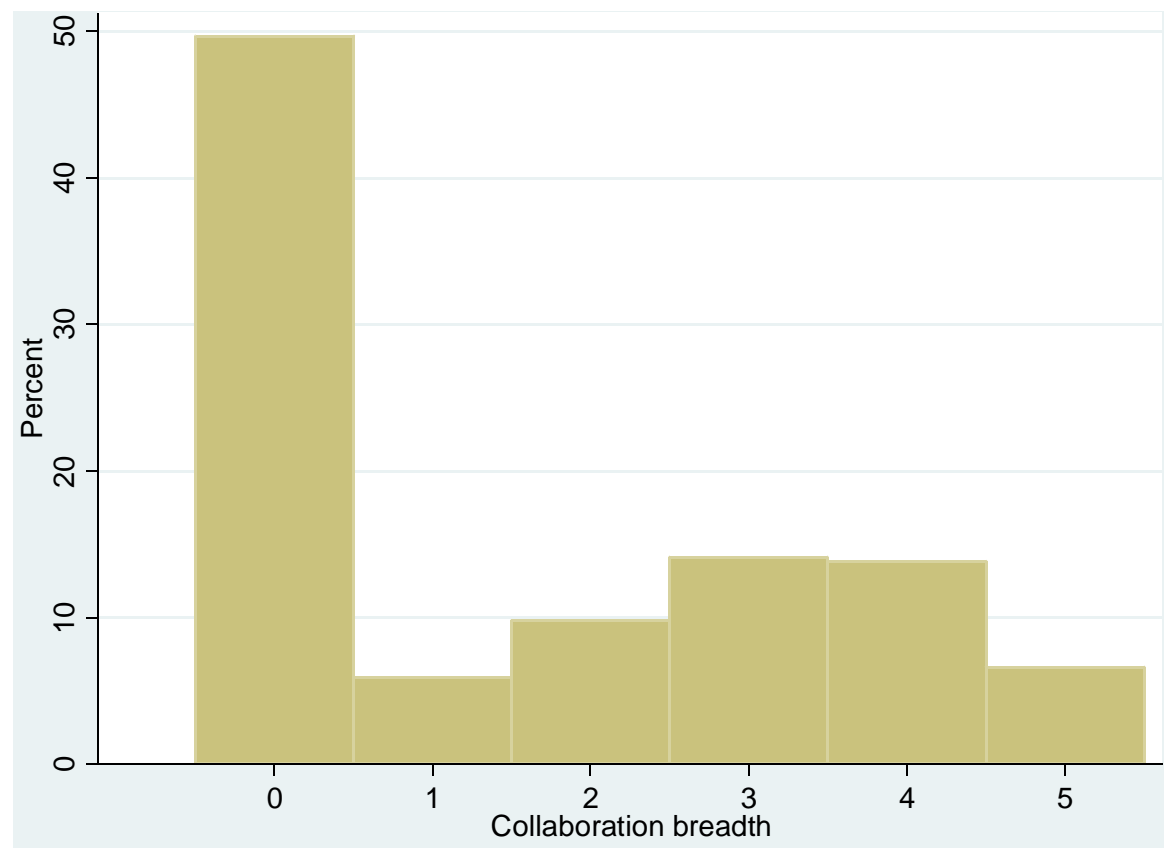

